\title{
KEWENANGAN PENGELOLAAN KEUANGAN LEMBAGA PERKREDITAN DESA (LPD) SETELAH BERLAKUNYA PERATURAN DAERAH NOMOR 29 TAHUN 2013
}

\author{
Made Ipunk Dwi Kusuma, I Nyoman Putu Budiartha, Diah Gayatri Sudibya \\ Fakultas Hukum Universitas Warmadewa, Denpasar-Bali, Indonesia \\ ipunkkusuma@yahoo.com, budiarthaputu59@gmailcom, diahgayatrisudibya@gmailcom
}

\begin{abstract}
Abstrak
Tujuan penelitian ini adalah untuk menjelaskan kewenangan pengelolaan keuangan LPD di Kabupaten Badung, setelah berlakunya Perda Kabupaten Badung No 29 Tahun 2013 dan mengetahui arah pemanfaatan dana pembinaan LPD di Kabupaten Badung. Penelitian ini menggunakan penelitian hukum normatif, dengan pendekatan perundang-undangan yang khusus mengatur tentang kewenangan pengelolaan keuangan LPD setelah berlakunya Perda Kabupaten Badung nomor 29 Tahun 2013. Sumber data yang digunakan adalah bahan hukum primer dan sekunder. Data dianalisis secara deskriptif kualitatif yaitu penyajian dengan menggambarkan secara lengkap tentang aspek-aspek tertentu yang terkait dengan masalah yang sedang diteliti. Hasil penelitian menunjukkan bahwa kewenangan pengaturan penyelenggaraan kegiatan lembaga pengkreditan desa di Kabupaten Badung masih ditangani oleh pemerintah Provinsi karena sampai sejauh ini Provinsi tidak pernah menyerahkan atau melimpahkan kewenangan tersebut kepada Kabupaten Badung, yang kedua pemanfaatan dana pembinaan lembaga pengkreditan desa untuk melakukan pembinaan terhadap LPD-LPD yang ada di Bali untuk meningkatkan kinerja dan kualitas sumber daya manusia pengurus LPD.
\end{abstract}

Kata Kunci: Kewenangan, Pengelolaan Keuangan, LPD

\begin{abstract}
The purpose of this research is to explain the authority of LPD financial management in Badung Regency, after the enactment of the Badung Regency Regulation No. 29/2013 and to find out the direction of the utilization of LPD coaching funds in Badung Regency. This research used normative legal research, with a statutory approach that specifically regulates the financial management authority of the LPD after the enactment of the Badung Regency Regulation number 29 of 2013. The data sources used were primary and secondary legal materials. The data were analyzed using descriptive qualitative method, namely the presentation by describing in detail certain aspects related to the problem being researched. The results showed that the authority to regulate the implementation of village credit institution activities in Badung Regency is still handled by the Provincial government because so far the Province has never handed over or delegated this authority to Badung Regency. Second, the utilization of village credit institution development funds is to provide guidance to LPDs in Bali and to improve the performance and quality of LPD management human resources.
\end{abstract}

Keywords: Authority, Financial Management, LPD

\section{PENDAHULUAN}

Negara tidak hanya memberatkan tujuan pada keamanan untuk masyarakat tetapi lebih diarahkan pada stabilitas perekonomian Nasional untuk menjamin kesejahteraan masyarakat. Menurut Insukindro, (2007) sistem keuangan (financial system) pada umumnya merupakan suatu kesatuan sistem yang dibentuk dari semua lembaga keuangan yang ada dan kegiatan utamanya dibidang keuangan adalah menarik dana dan menyalurkannya kepada masyarakat.

Fungsi keberadaan sistem keuangan ini dapat melaksanakan sebagai lembaga perantara keuangan dan lembaga transmisi yang mampu menjembatani mereka yang kelebihan dana dan kekurangan dana serta memperlancar transaksi ekonomi (Wiwoho, 2014). Salah satu lembaga keuangan selain Bank di Bali adalah lembaga pengrkreditan desa (LPD) yang didirikan oleh Prof Dr Ida Bagus Mantra yang pada saat itu menjabat sebagai Gubernur Provinsi Bali. Lembaga pengkreditan desa berbeda dengan sistem perbankan pada umumnya yang lebih mengutamakan kesejahteraan dan kepentingan masyarakat. Lembaga pengkreditan desa merupakan badan usaha milik desa yang melaksanakan 
kegiatan usaha di lingkungan desa dan untuk krama desa sebagai salah satu bentuk pelaba baru milik desa adat yang nantinya dapat dipergunakan baik yang bersifat fisik maupun non fisik.

Pembentukkan lembaga pengkreditan desa di Bali membutuhkan waktu kurang lebih dua tahun untuk merealisasikan yang direalisasikan berdasarkan fenomena yang dihadapi dalam budaya Bali yang pelaksanaannya berada di pedesaan serta aktivitasnya dilakukan oleh lembaga adat yang ada sesuai dengan desa kala patra setempat (situasi menurut tempat waktu dan keadaan) (Surpha, 2004). Berdasarkan Perda Provinsi Bali No 3 Tahun 2017 tentang Lembaga Pengkreditan Desa bahwa Kabupaten Badung merupakan salah satu dari Kabupaten yang ada di wilayah provinsi Bali dengan luas wilayah $41852 \mathrm{Km}^{2}$ terdiri dari enam (6) kecamatan 16 kelurahan 46 desa dan 120 desa adat yang tersebar di masing-masing kecamatan sampai saat ini telah memiliki 118 (seratus delapan belas) Lembaga Pengkreditan Desa dari 120 desa Pakraman yang ada (Sudarmini et al., 2017).

Keluarnya Perda Kabupaten Badung 29 Tahun 2013 sebagai pengganti Perda Kabupaten Badung Nomor 19 Tahun 2001 tentang Lembaga Pengkreditan Desa sesuai dengan peraturan Daerah Provinsi Bali Nomor 8 Tahun 2002 terkait dengan pengelolaan Lembaga Pengkreditan Desa khususnya terhadap penyetoran dana pembinaan sesuai Peraturan Daerah Provinsi Bali disetor ke Bank Pembangunan Daerah Provinsi. Badan Pengkredita Desa merupakan salah satu bank umum milik pemerintah (Suyatno, 2007). Dalam melakukan transaksi kredit dengan menggunakan jaminan benda tetap berupa tanah, dijaminan di LPD mengacu kepada Undang-Undang Hak Tanggungan, sedangkan transaksi kredit dengan menggunakan jaminan benda bergerak pengikatannya mengacu kepada Undang-Undang Jaminan Fidusial (Jayanthi et al., 2016). Hal ini merupakan konsekuensi dari pada cikal bakal terbentuknya serta kebersamaan dalam pengembangan dan pelestarian Lembaga Pengkreditan Desa di Bali sebagai sebuah lembaga yang memiliki karakteristik dan ciri khas tersendiri. Pembentukan perda No 29 Tahun 2013 merupakan untuk mewujudkan LPD dalam mendorong perekonomian desa adat dan meningkatkan kesejahteraan masyarakat. Tujuan penelitian ini adalah Untuk mengetahui kewenangan pengelolaan keuangan LPD di Kabupaten Badung setelah berlakunya Perda Kabupaten Badung No 29 Tahun 2013 dan mengetahui arah pemanfaatan dana pembinaan LPD di Kabupaten Badung.

\section{METODE PENELITIAN}

Penelitian ini menggunakan penelitian hukum normatif, melalui pendekatan pendekatan perundangundangan yang khusus mengatur tentang kewenangan pengelolaan keuangan lembaga pengkreditan desa setelah berlakunya Perda Kabupaten Badung Nomor 29 Tahun 2013. Bahan hukum yang digunakan adalah bahan hukum primer (authoritative records) dan bahan hukum sekunder (secondaire records) (Hartono, 1994). Bahan hukum primer adalah berupa peraturan perundang-undangan dan peraturan daerah, sedangkan bahan hukum sekunder yaitu bahan hukum yang berisikan informasi tentang bahan hukum primer seperti buku-buku atau literatur yang berkaitan dengan skripsi ini. Dalam mengumpulkan informasi dan bahan hukum digunakan teknik analisis deskriptif kualitatif artinya penyajian dengan menggambarkan secara lengkap tentang aspek-aspek tertentu yang bersangkut paut dengan masalah yang kemudian dianalisis kebenarannya dengan teknik ini maka semua informasi dan bahan hukum yang diperoleh dikumpulkan yang selanjutnya dilakukan suatu analisis dan dicari pemecahannya menurut ketentuan hukum yang berlaku sehingga dapat ditarik suatu kesimpulan (Sugiyono, 2005).

\section{HASIL DAN PEMBAHASAN}

\section{Terbentuknya Perda Kabupaten Badung Nomor 29 Tahun 2013 tentang LPD}

Negara Republik Indonesia terdiri dari bebrapa Kabupaten Kota yang berhak mengatur dan mengurus rumah tangganya sendiri yang terbagi kedalam tiga wilayah yaitu Provinsi, Kabupaten atau Kota Madya serta kecamatan. Masing-maisng memilik kewenangan tersendiri yang bersifat otonom. Perda provinsi Bali dan Perda Kabupaten Badung menyatakan desa berhak memiliki sebuah lembaga keuangan desa yang disebut dengan LPD.

Ketentuan pasal di atas jelas memberikan kewenangan yang lebih luas kepada Kabupaten dalam artian pengawasan dari provinsi terhadap penyelenggaraan kegiatan di Kabupaten terkait dengan pembentukan peraturan daerah itu sendiri lebih ditekankan pada pengawasan yang sifatnya represif bukan preventif (Sunarno, 2009). Dasar ketentuan pasal 4 tersebut Kabupaten Badung membentuk 
Peraturan Daerah Nomor 29 Tahun 2013 tentang Lembaga Perkreditan Desa tanpa mengacu dan menjadikan Perda Provinsi sebelumnya yaitu Peraturan Daerah Provinsi Bali Nomor 8 Tahun 2002 tentang Lembaga Perkreditan Desa sebagai dasar hukum agar tercipta keserasian hubungan antara Provinsi dengan Kabupaten

Pada sisi lain Perda Kabupaten Badung Justru bertentangan dengan Perda Provinsi terutamanya dalam hal penyetoran dana pembinaan lembaga perkreditan desa yang ada di Kabupaten Badung yang jumlahnya mencapai milyaran rupiah pertahun. Disini terlihat Badung ingin mengambil alih pengaturan terhadap lembaga perkreditan desa. Kewenangan terhadap pengaturan kegiatan lembaga perkreditan desa dipegang oleh Provinsi sebagai konsekuensi cikal bakal terbentuknya lembaga perkreditan desa. Terbitnya Undang-Undang Republik Indonesia Nomor 32 Tahun 2004 sebagai pengganti UndangUndang Nomor 22 Tahun 1999 mengakibatkan posisi Perda Badung justru semakin lemah dalam Undang-Undang Nomor 32 Tahun 2004 tidak ada ditegaskan bahwa antara Kabupaten dengan Provinsi tidak terdapat hirarki atau tingkatan seperti yang dijelaskan dalam Undang-Undang Nomor 22 Tahun 1999. Dari ketentuan tersebut terlihat adanya hubungan wewenang antara Pemerintah Kabupaten dengan Pemerintah Provinsi Jika dihubungkan dengan keberadaan Perda LPD tersebut maka setiap tindakan Pemerintah berkaitan dengan kewenangan Pemerintah Provinsi apalagi dalam hal pengaturan dengan pembentukan Perda LPD maka tindakan tersebut harus didasarkan adanya penyerahan kewenangan oleh Provinsi Kepada Kabupaten.

Lembaga perkreditan desa di Kabupaten Badung yang pada awalnya berdiri baik itu berasal dari swadaya masyarakat bantuan pemerintah atau sumber lain telah mengalami perkembangan modal asset serta keuntungan yang sangat pesat semakin memperkokoh eksistensi atau keberadaannya. Terbentuknya Perda Kabupaten tentang LPD tidak terlalu berpengaruh terhadap perkembangan modal maupun jumlah aset LPD di Kabupaten Badung walaupun tidak dapat disangkal bahwa ada kebingungan diantara LPD-LPD yang ada untuk mengacu pada Perda Provinsi atau Kabupaten namun hal tersebut tidak menghambat perkembangan LPD khususnya di Kabupaten Badung.

Peningkatan jumlah modal asset serta keuntungan LPD tersebut telah menciptakan perluasan lapangan pekerjaan bagi masyarakat desa pakraman dimana hal ini terlihat bahwa jumlah tenaga kerja LPD baik itu sifatnya sebagai pengurus maupun karyawan selalu bertambah dari tahun ketahun Tahun 2014 jumlah tenaga kerja LPD adalah sebanyak 859 orang, tahun 2015 menjadi 973 orang, tahun 2016 bertambah sebanyak 17 orang menjadi 990, tahun 2017 sebanyak 1054 orang dan terakhir tahun 2018 jumlah tenaga kerja LPD adalah sebanyak 1073 orang (wawancara dengan IB Warnaya selaku Ketua LPD Kab Badung Jumat 10 Januari 2020)

Dalam perjalanan LPD sampai saat ini proses pembenahan pemberdayaan terhadap potensi yang ada serta kemajuan yang telah dicapai baik secara sosial kemasyarakatan operasional maupun keuntungan menunjukkan suatu perkembangan yang terus meningkat Dibalik kemajuan-kemajuan yang telah diraih baik secara sosial dan ekonomis dalam menjalankan roda operasional lembaga keuangan masih banyak kendala yang harus dihadapi terutamanya ketersediaan sumber daya manusia yang tangguh dan berkualitas baik pengurus maupun badan pengawas masih sangat terbatas. Berdasarkan laporan yang diperoleh dari PLPDK Kabupaten Badung sebagai tim pembina terhadap keberadaan LPD yang ada dimasing-masing wilayah binaannya masing-masing secara umum teridentifikasi beberapa permasalahan baik operasional maupun pengawasan antara lain:

1. Ketersediaan sumber daya manusia dalam rangka menjalankan operasional belum sesuai dengan harapan sehingga proses dan prosedur administrasi belum mengacu pada peraturan yang ada sehingga rentan terhadap permasalahan maupun proses

2. Keterbatasan sarana dan prasarana terutama pada LPD yang mempunyai aset kecil sehingga memberikan dampak terhadap proses pelayanan pada masyarakat karena masih dilakukan secara manual

3. Kurangnya pemahaman krama sebagai pemilik dan pengelola tentang eksistensi LPD serta adanya wacana yang masih berkembang bahwa keberadaan LPD yang ada sepenuhnya merupakan tanggung jawab pemerintah

4. Adanya pergantian baik pengurus maupun pengawas sudah tidak sesuai dengan mekanisme yang ada

Seiring perkembangan fungsi lembaga pengkreditan desa sehingga banyak masyarakat yang mengambil pinjaman, adapun beberapa tantangan yang dihadapi LPD saat ini yaitu: 
1) Membenahi sistem pengelolaan mengarah pada profesionalisme menuju pelayanan prima sehingga mampu bertahan dan bersaing pada era globalisas

2) Memotivasi masyarakat khususnya krama Bali untuk memahami dan menyadari pentingnya LPD yang merupakan salah satu aset yang mempunyai peranan yang sangat strategis dalam pengembangan dan pelestarian budaya sebagai pilar yang kokoh dalam menunjang pariwisata

3) Menarik minat generasi muda yang potensial yang ada di pedesaan untuk mau mengabdikan diri dalam pengembangan dan pelestarian LPD kedepan

4) Menyiapkan sumber daya manusia yang handal sehingga siap bersaing serta mampu menyelesaikan permasalahan yang muncul kedepannya (wawancara dengan IB Warnaya selaku Ketua LPD Kab Badung Jumat 10 Januari 2020)

\section{Arah Pemanfaatan Dana Pembinaan LPD di Kabupaten Badung}

Perbedaan pokok antara Perda Provinsi dengan Perda Kabupaten adalah tentang penyetoran dana pembinaan serta pemanfaatannya, selain itu tentang kewenangan pembentukan LPD Kemana sebenarnya dana pembinaan ini disalurkan dan dimanfaatkan sehingga hal ini menimbulkan permasalahan antara Kabupaten dengan Provinsi. Setelah keluarnya Perda Kabupaten tentang LPD kabupaten terkesan menginginkan dana ini untuk bisa dikelola sendiri. Dari ketentuan tersebut diketahui bahwa besarnya dana pembinaan yang disetorkan LPD setiap tahunnya adalah 5\% dari keuntungan bersihnya Jumlah dana $5 \%$ dari 1 LPD mungkin tidak terlalu besar namun bisa dibayangkan apabila dana tersebut dikalikan 118 (seratus delapan belas) LPD yang ada di kabupaten Badung jumlahnya bisa mencapai ratusan juta tiap bahkan mencapai milyaran rupiah setiap tahunnya

Sesuai ketentuan Perda Kabupaten dimana dana tersebut tidak disetorkan kepada BPD maka keuntungan utama yang didapati oleh Kabupaten Badung adalah dana sebesar 10\% dari total dana pembinaan yang diperoleh tidak disetorkan kepada BPD melainkan dikelola sendiri oleh Kabupaten. Arah pemanfaatan dana pembinaan ini oleh Kabupaten Badung sampai sekarang masih belum jelas karena belum ada Keputusan Bupati yang mengatur tentang pemanfaatan dana pembinaan tersebut sebagai tindak lanjut dari Perda Kabupaten Sampai sekarang dana pembinaan yang dipegang oleh BKS LPD Kabupaten Badung masih beku belum dimanfaatkan sama sekali sejak tahun 2013.

Lembaga perkreditan desa diharapkan menjadi penggerak perekonomian di pedesaan serta mendukung pelestarian budaya yang diwariskan secara turun temurun sebagai pemilik Desa Pakraman mempunyai kewenangan penuh terhadap pengelolaan dan pengawasan pengoperasian kegiatan LPD. Kewenangan tersebut terlihat diantaranya dalam hal pengangkatan dan pemberhentian pengurus, penentuan suku bunga LPD menyelesaikan sengketa yang terjadi dalam LPD, menjatuhkan sanksi terhadap pengurus yang melakukan penyimpangan. Selektivitas krama desa dalam hal pemilihan pengurus merupakan suatu yang sangat penting agar kelak LPD dipimpin dan dikelola oleh orangorang yang berkualitas dan berpotensi menjadikan LPD tersebut lebih maju.

Pengurus merupakan pihak yang sangat penting peranannya dalam kemajuan LPD itu sendiri, dalam menjalankan fungsinya pengurus berada di bawah pengawasan Badan Pengawas yang terdiri dari 2 (dua) orang anggota yang dipilih oleh krama desa dan diketuai langsung oleh Bendesa adat ketua dan anggota pengawas tidak diperbolehkan ikut sebagai pengurus demi terciptanya disiplin manajemen dalam lembaga perkreditan desa pakraman ini. Pengawas pengurus dan pegawai LPD harus jelas walaupun secara kenyataan di dalam lembaga adat ini masih ada tumpang tindih terhadap manajemennya. Tumpang tindih yang dimaksud adalah manajemen atau struktur kepengurusan masih ada pengurus yang merangkap jabatan namun hal tersebut secara perlahan diharapkan bisa teratasi dengan dilakukannya pembinaan secara intensif. Kewenangan penentuan suku bunga LPD baik itu suku bunga tabungan deposito maupun kredit berada di tangan desa pakraman yang ditetapkan melalui kesepakatan pada paruman (rapat) Desa pakraman dengan tetap mengacu pada standar bunga

Tata cara pemecahan masalah yang dihadapi LPD tetap terlebih dahulu dilakukan dengan jalan musyawarah namun apabila hal tersebut tidak bisa dicarikan solusinya secara musyawarah maka barulah ditempuh jalur hukum Sementara itu Kabupaten sebagai tim pembina LPD disini perannya cukup penting juga dimana kabupaten banyak memberikan saran-saran dan masukan terhadap krama desa yang LPD-nya mengalami permasalahan namun saran dan masukkan yang diberikan sifatnya hanya sebagai pertimbangan bukan serta merta harus dilaksanakan sebab yang berwenang secara penuh dalam hal ini adalah krama desa itu sendiri 


\section{SIMPULAN DAN SARAN}

\section{Simpulan}

Dari hasil analisis data, dapat disimpulkan bahwa kewenangan pengaturan penyelenggaraan kegiatan LPD di Kabupaten Badung masih ada pada Provinsi karena sampai sejauh ini Provinsi tidak pernah menyerahkan atau melimpahkan kewenangan tersebut kepada Kabupaten, yang kedua pemanfaatan dana pembinaan LPD adalah untuk melakukan pembinaan terhadap LPD-LPD yang ada di Bali untuk meningkatkan kinerja dan kualitas sumber daya manusia pengurus LPD

\section{Saran}

Adapun yang menjadi saran yaitu diharapkan kepada pemerintah propinsi Bali memberi kewenangan kepaada pemerintah tingkat kabupaten masing-masing untuk membuat peraturan sendiri, yang kedua untuk dana pembinaan hendaknya dapat digunakan untuk melakukan pembinaan terhadap LPD-LPD yang ada di Bali sehingga kinerja dan kualitas sumber daya manusia pengurus LPD dapat ditingkatkan

\section{DAFTAR PUSTAKA}

Hartono. (1994). Penelitian Hukum di Indonesia pada Akhir Abad 20. Alumni. Insukindro. (2007). Hukum Perbankan Nasional Indonesia. Kencana Prenada Media Group.

Jayanthi, N. M. D., Wairocana, I. G. i N., \& Wiryawan, I. W. (2016). Status dan Kedudukan Lembaga Perkreditan Desa (LPD) Terkait Pengikatan Jaminan dengan Berlakunya Undang-Undang Nomor 1 Tahun 2013 tentang Lembaga Keuangan Mikro Oleh. Jurnal Ilmiah Prodi Magister Kenotariatan, 1(2), 201-212.

Sudarmini, K., Pt.Rediatnigiri, N., \& Rustini, N. M. (2017). Pegaruh Rasio-Rasio Cael terhadap Tingkat Kesehatan LPD di Kecamatan Mengwi Kabupaten Badung. Jurnal Wicaksana, Jurnal Lingkungan \& Pembangunan, 1(1), 23-32.

Sugiyono. (2005). MemahamiPenelitian Kualitatif. Alfabeta.

Sunarno. (2009). Hukum Pemerintahan Daerah di Indonesia. Sinar Grafika.

Surpha, I. W. (2004). Eksistensi Desa Adat dan Dinas di Bali. Pustaka Bali Post.

Suyatno, T. (2007). Dasar-dasar Perkreditan Edisi Keempat. Gramedia Pustaka Utama.

Wiwoho, J. (2014). Distribusi Keadilan Bagi Masyarakat. Jurnal MMH, 43(1), 87-97. 